\title{
PREPARATION OF IMMUNOSTIMULATING COMPLEXES (ISCOM) CONTAINING BOVINE HERPESVIRUS 1 PROTEINS
}

\author{
J. FRANZ, J. HAMPL, J. ŠTĚPANEK and B. SMID \\ Veterinary Research Institute, 62132 Brno
}

Received November 28, 1991

\begin{abstract}
Franz J., J. Hampl, J. Štěpánek, B. Šmíd: Preparation of Immunostimulating Complexes (ISCOM) Containing Bovine Herpesvirus 1 Proteins. Acta vet. Brno, 61, 1992: 37-41.

A method for obtaining ISCOMs with incorporated bovine herpesvirus 1 (BHV-1) proteins from various amounts of cholesterol, phosphatidylcholine and Quil $\mathbf{A}$ is described. The highest virus protein incorporation rate obtained was $25 \%$. Morphology of ISCOMs depended on amounts of Quil A, cholesterol and phosphatidylcholine used. A high immunogenicity of BHV-1-ISCOM, as compared with free virusproteins, was confirmed experimentally in mice.
\end{abstract}

Bovine herpesvirus $B H V-1$, virus protein, ISCOM, antibody response

One of the essential means for the control of virus diseases of farm animalsare vaccines, capable of inducing specific resistance against the causal agent in individual animals and animal populations. Current technologies use suspensions of complete virus particles propagated in cell cultures or laboratory animals. In addition to the specific immunogenic antigen, such suspensions contain a number of other proteins, originating from culture media, disintegrated cells or even microbial contaminants. Such a broad antigenic spectrum, reaching far beyond the purpose of vaccination, is unwanted and therefore alternative methods for producing quality biologicals are developed currently.

Progressive trends in the control of virus diseases are focussed on the development of subunit vaccines. Protein subunits are prepared by highly effective purification procedures or by biotechnological methods, such as chemical synthesis of peptides or DNA recombination. However, the development of subunit vaccines is complicated by the rather low antigenicity of separated immunostimulants or adjuvants (Liu and Čepica 1990; Rowland 1986; Zanetti et al. 1987; Dougan 1985). On the other hand, procedures involving incorporation of virus subunits with specific antigenic determinants into submicroscopical structures, generally called immunostimulating complexes (ISCOMs), appear to be prospective (Morein et al. 1984). The spatial arrangement of ISCOMs imitates that of small virus particles, the high immunogenicity of which has been confirmed repeatedly (Trudel et al. 1987; Morein et al. 1987; Berezin et al. 1988; Merza et al. 1988; Cook et al. 1990; Löv gren and Morein, 1991; Thapar et al. 1991).

The aim of our experiments was to develop an efficient procedure for the incorporation of bovine herpesvirus 1 (BHV-1) protein subunits into ISCOM and to examine the morphology and immunogenicity of the complexes formed.

\section{Materials and Methods}

Virus propagation and purification

Strain Los Angeles of BHV-1, the causal agent of infectious bovine rhinotracheitis, was propagated in primary calf kidney cell cultures. The virus was harvested after repeated freezing-thawing as soon as CPE became apparent, i. e. after 2-3 days of incubation. Cell debris was removed by low-speed centrifugation, the infective culture fluid was concentrated by ultrafiltration and the concentrated suspension was purified by ultracentrifugation (Beckman L8-80 M) in potassium tartrate density gradient ( $T r u d e l$ et al. 1987). Virus-containing fractions were pooled and centri- 
fugated and the sediment was resuspended in TEN buffer. The virus content was checked by titration in cell cultures and by electron microscopy.

Virus protein subunits

The suspension of the purified virus was incubated with the non-ionogenic detergent 1-0-n-octyl-glucopyranoside. Nucleocapsids were separated by ultracentrifugation in saccharose density gradient and the protein content in the supernatant was determined by Lowry's (1951) method.

\section{ISCOM}

Quil A, cholesterol (C) and phosphatidylcholine (PC) were added in various weight proportions to the supernatant containing saccharose and virus protein subunits and the mixture was dialyzed against a large volume of $0.1 \mathrm{M}$ ammonium acetate $(\mathrm{pH} 7.0$ ) for 48 hours. The ISCOMs formed were separated into the sediment by 4 hours ultracentrifugation at $40000 \mathrm{r} . \mathrm{p}$. $\mathrm{m}$. using the rotor SW $55 \mathrm{Ti}$. The rate of protein incorporation into ISCOM was determined by the addition of a standard amount of ${ }^{125} \mathrm{I}$-labelled homologous protein per $500 \mu \mathrm{g}$ virus protein subunits. $0.0 \mu \mathrm{g}, 50 \mu \mathrm{g}$, $250 \mu \mathrm{g}, 500 \mu \mathrm{g}, 1000 \mu \mathrm{g}$ or $1500 \mu \mathrm{g}$ of $\mathrm{C}$ and PC, and $2000, \mu \mathrm{g}$ or - in one case $-4000 \mu \mathrm{g}$ Quil A were used in individual incorporation experiments.

Electron microscopy

The morphology of ISCOMs was examined by electron microscopy. Negative staining with $2 \%$ ammonium molybdate ( $\mathrm{pH} 6.8-7.0$ ) was used.

Immunization

Immunogenicity of BHV-1-ISCOMs, prepared under various conditions, was examined in Balb/c mice. Eight groups of 10-16 mice were inoculated subcutaneously with $1.0 \mu \mathrm{g}$ BHV-1 protein incorporated into ISCOM and the same dose was repeated on Day 21 p. i. Blood sera for the determination of antibodies to BHV-1 were obtained by successive exsanguinations of mice 21,35 and 49 days after the first treatment. Mice in the control group were inoculated and reinoculated with $10 \mu \mathrm{g}$ of free virus protein.

Antibody determination by ELISA

The indirect method with complete, solid phase-bound BHV-1 as antigen was used. The conjugate was prepared by labelling porcine anti-mouse antibodies, purified by affinite chromatography with horse radish peroxidase. Hydrogen peroxide and tetramethylbenzidine were used as substrate. Blood sera were examined in serial twofold dilutions starting with $1: 50$. The results were expressed as mean titres of BHV-1 antibodies.

\section{Results}

Weight proportions of ISCOM components, i. e. virus subunit proteins, Quil A, C and PC and respective rates of virus protein incorporation are given in Table 1. The highest incorporation rate, i. e. $25 \%$, at the constant amounts of $500 \mu \mathrm{g}$ virus protein and $2000 \mu \mathrm{g}$ Quil A was reached when $250 \mu \mathrm{g} \mathrm{C}$ and $250 \mu \mathrm{g}$ PC were used. Only 9.8 and $7.8 \%$ of the protein was incorporated into ISCOMs prepared without $\mathrm{C}$ and $\mathrm{PC}$ and with $50 \mu \mathrm{g} \mathrm{C}$ and $50 \mu \mathrm{g} \mathrm{PC}$, respectively. Excess of C and PC (1000 or $1500 \mu \mathrm{g})$ reduced the incorporation rate to $15 \%$, but the use of $4000 \mu \mathrm{g}$ Quil A resulted in an increase to $23.3 \%$.

Electron microscopic examinations confirmed the formation of typical spatial cage-like structuresin all experiments (Plate XXIII, Fig. 1). The size of ISCOM particles rose from approx. 20 to $60 \mathrm{~nm}$ when the amounts of $C$ and PC increased (Fig. 2,3,5). Aggregation of particles or formation of extensive ISCOM complexes were observed when 1000 or $1500 \mu \mathrm{g} \mathrm{C}$ and PC were combined with $2000 \mu \mathrm{g}$ Quil A (Plates XXIV., XXV., Fig. 4, 6). The formation of the aggregates and complexes was prevented by increasing the amount of Quil A to $4000 \mu \mathrm{g}$ (Fig. 5).

A very weak antibody response was recorded in the control group inoculated with free BHV-1 proteins. Antibodies were detectable on Day $49 \mathrm{p}$. i. only. The most intensive antibody response was recorded in Group 3 (Table 1), treated with ISCOMs with the highest virus protein incorporation rate. This applied 
Rate incoirporation of BHV-1 protein into ISCOM and antibody responses in mice after subcutaneous administration

\begin{tabular}{|c|c|c|c|c|c|c|c|c|c|}
\hline \multirow{2}{*}{ Group } & \multirow{2}{*}{$\begin{array}{l}\text { Number } \\
\text { of mice }\end{array}$} & \multicolumn{4}{|c|}{$\dot{\mu}_{\mathrm{g}}$} & \multirow{2}{*}{$\stackrel{\%}{\%}$ incorporation } & \multicolumn{3}{|c|}{ ELISA titre days p. $i}$. \\
\hline & & $\mathbf{C}^{*}$ & PC* & Quil A & Protein BHV-1 & & 21 & 35 & 49 \\
\hline $\begin{array}{l}1 \\
2 \\
3 \\
4 \\
5 \\
6 \\
7\end{array}$ & $\begin{array}{l}16 \\
16 \\
10 \\
10 \\
16 \\
16 \\
16\end{array}$ & $\begin{array}{r}0 \\
50 \\
250 \\
500 \\
1000 \\
1500 \\
1000\end{array}$ & $\begin{array}{r}0 \\
50 \\
250 \\
500 \\
1000 \\
1500 \\
1000\end{array}$ & $\begin{array}{l}2000 \\
2000 \\
2000 \\
2000 \\
2000 \\
2000 \\
4000\end{array}$ & $\begin{array}{l}500 \\
500 \\
500 \\
500 \\
500 \\
500 \\
500\end{array}$ & $\begin{array}{r}9.8 \\
7.8 \\
25.0 \\
20.7 \\
15.5 \\
14.7 \\
23.3\end{array}$ & $\begin{array}{r}800 \\
20 \\
433 \\
150 \\
60 \\
0 \\
\text { ND }^{* *}\end{array}$ & $\begin{array}{r}3040 \\
2570 \\
4800 \\
83 \\
20 \\
0 \\
\mathrm{ND}\end{array}$ & $\begin{array}{r}2240 \\
1220 \\
5330 \\
1333 \\
462 \\
0 \\
\text { ND }\end{array}$ \\
\hline 8 & 16 & \multicolumn{4}{|c|}{ free virus protein } & - & 0 & $\mathbf{0}$ & 100 \\
\hline
\end{tabular}

All mice were reinoculated on Day $21 \mathrm{p}$. i. The dose was $1 \mu \mathrm{g}$ protein ISCOM in all animals. The dose of free virus protein was $10 \mu \mathrm{g}$.

${ }^{*} \mathrm{C}=$ cholesterol, $\mathrm{PC}=$ phosphatidylcholine

**ND = not examined - all mice died within 24 hours

for both Day 35 and Day 49 p. i. Very low antibody titres or absence of antibodies were observed in mice treated with ISCOMs arranged into large aggregates (Groups 5 and 6). A twofold elevation of the content of Quil A (Group 7) resulted in an increase of the incorporation rate to a level comparable with that used in Group 5, but all treated mice died within 24 hours.

\section{Discussion}

The starting point of our experiments was the information of Morein et al. (1984), who described a new type of a subunit vaccine based on the immunostimulating complex - ISCOM - in which the antigen is arranged into a spatial structure formed by an adjuvant and a lipid component. The ISCOM matrix is formed by the glycoside Quil A, cholesterol and, as the case may be, phosphatidylcholine in optimal proportions. Specific microbial antigens can be incorporated into such matrices by hydrophobic interactions. As confirmed for pseudorabies (Morein et al. 1989), influenza (Lövgren et al. 1990; Weiss et al. 1990), bovine leucosis (Merza et al. 1989) and BHV-1 (Trudel et al. 1988; Merza et al. 1988) viruses, Toxoplasma gondii (Overnes et al. 1991) and other causal agents, antigens arranged in such a manner show a high immunogenicity. Envelope proteins of BHV-1, the causal agent of a widespread and serious disease of cattle, were used as a model in our experiments. Preliminary experiments showed a rather low rate of BHV-1 protein incorporation into ISCOM (less than $10 \%$ ), however. Therefore we attempted to enhance the incorporation by defined amounts of cholesterol and phosphatidylcholine. The incorporation rate reached its maximum of $25 \%$ when $250 \mu \mathrm{g}$ cholesterol, $250 \mu \mathrm{g}$ phosphatidylcholine and $2000 \mu \mathrm{g}$ Quil A per $500 \mu \mathrm{g}$ virus protein were used. Such BHV-1-ISCOMs showed also the highest immunogenicity in mice. Similar results were reported by Lövgren and Morein (1989), who stressed that the matrix-forming lipids are essential when highly purified proteins are used as the antigen.

All ISCOMs, prepared by any of the modification of the procedure, showed the typical cage-like structures, as described by Özel et al. (1989), e. g. However, elevated amounts of cholesterol and phosphatidylcholine at the constant amount of proteins led to an increase of the size if ISCOMs up to the formation of large 
aggregates. This fact has not been described in available literature. In similar experiments, Lövgren and Morein (1988) found a partial reduction of the sedimentation constant, but no morphological deviations of ISCOMs. It is noteworthy in this conection that immune responses of mice inoculated with BHV-1-ISCOM aggregates were very weak or absent. We suppose that the specific antigenic determinants in ISCOM aggregates are not readily accessible to immunity-mediating cells. The formation of the aggregates could be prevented by a twofold increase of the proportion of Quil A, but such combination appeared to be toxic in our experiments.

The results of our experiments and other available information let us conclude that ISCOMs are a prospectful component for further development of subunit vaccines. This applies especially to the use of specific proteins obtained either by DNA recombination, or by chemical synthesis.

\section{Příprava imunostimulačních komplexů (ISCOM) z proteinů viru BHV-1}

Je popsána metoda př́pravy ISCOMu s inkorporovaným proteinem viru BHV-1 za použití různého množství cholesterolu, fosfatidylcholinu a Quilu A. $\mathrm{V}$ optimálním př́ípadě bylo dosaženo $25 \%$ inkorporace virového proteinu. Morfologický charakter ISCOMů byl ovliněn množstvím použitého Quilu $\mathrm{A}$, cholesterolu a fosfatidylcholinu. V imunizačním pokusu na myších byla potvrzena vysoká imunogenní účinnost BHV-1-ISCOMu ve srovnání se samotnými virovými proteiny.

\section{Подготовка иммүностимүлирүющих комплексов (ISCOM) из протеинов вируса BHV-1}

Дается описание метода подготовки иммуностимулирующих комплексов с введенным протеином вируса BHV-1 при применении разного количества холестерина, фосфатидилхолина и Квила А. В оптимальном случае было достигнуто $25 \%$ инкорпорации вирусного протеина. Морфологический характер ISCOМов оказался под влиянием количества примененного Квила А, холестерина и фоссатидилхолина. В проводимых на мышах эксперименте иммунизации был подтвержден высокий иммүногенный эффект BHV-1-ISCOMа по сравнению с собственными вирусными протеинами.

\section{References}

BEREZIN, V. E. -ZAIDES, V. M.-ISAEVA, E. S.-ARTAMONOV, A. F.-ZHDANOV, V. M.: Controlled organization of multimolecular complexes of enveloped virus glycoproteins: study of immunogenicity. Vaccine, $6,1988: 450-456$

COOK, R. F.-O'NEILL, T.-STRACHAN, E.-SUNDQUIST, B.-MUMFORD, J. A.: Protection against lethal equine herpes virus type 1 (subtype 1) infection in hamsters by immune stimulating complexes (ISCOMs) containing the major viral glycoproteins. Vaccine, 8, 1990: $491-496$

DOUGAN, G.: Genetic approaches to the development of new vaccines. Irish vet. J., 39, 1985: 96-105

LIU, J.-CEPICA, A.: Current approaches to vaccine preparation. Can. vet. J., 31, 1990: 181 to 184 
LÖVGREN, K.-MOREIN, B.: The ISCOM: an antigen delivery system with built-in adjuvant. Molec. Immunol., 28, 1991: 285-296

LÖVGREN, K.-KABERG, H.-MOREIN, B.: An experimental influenza subunit vaccine (ISCOM): induction of protective immunity to challenge infection in mice after intranasal or subcutaneous administration. Clin. exp. Immunol., 82, 1990: 435-439

LÖVGREN, K.-MOREIN, B.: The requirement of lipids for the formation of immunostimulating complexes (ISCOMs). Biotechnol. appl. Biochem., 10, 1988: 161-172

LOWRY, O. H.-ROSENBROUGH, N. J.-FARR, A. L.-RANDAL, R. J.: Protein measurement with the folic phenol reagent. J. Biol. Chem., 193, 1951: 265-275

MERZA, M.,-BELÁK, S.-MOREIN, B.: Characterization of an ISCOM prepared with envelope glycoproteins of bovine herpesvirus type 1. J. Vet. Med. B., 35, 1988: 695-703

MERZA, M. S.-LINNÉ, T.-HÖGLUND, S.-PORTETELLE, D. - BURNY, A. - MOREIN, B.: Bovine leukaemia virus ISCOMs: biochemical characterization. Vaccine, 7, 1989: $20-28$

MOREIN, B. - SUNDQVIST, B.-HOGLUND, S. -DALSGAARD, K.-OSTERHAUS, A.: ISCOM, a novel structure for antigen presentation of membrane proteins from enveloped viruses. Nature, 308, 1984: 457-460

MOREIN, B.-LÖVGREN, K.-HÖGLUND, S.-SUNDQUIST, B.: The ISCOM: an immunostimulating complex. Immunology Today, 8, 1987: 333-338

MOREIN, B.-BELÁK, S.-SOÓS, T.-RUSVAI, M.-McGWIRE, B. S.-BOGNÁR, K.: ISCOM of viral envelope proteins protects against Aujeszky's disease. Vet. Microbiol., 20, 1989: 143-154

OVERNES, G.-NESSE, L. L.-WALDELAND, H.-LÖVGREN, K.-GUDDING, R.: Immune response after immunization with an experimental Toxoplasma gondii ISCOM vaccine. Vaccine, 9, 1991: 25-28

ÖZEL, M.-HÖGLUND, S. - GELDERBLOM, H. R.-MOREIN, B.: Quaternary structure of the immunostimulating complex (ISCOM). J. Ultrastruct. molec. Struct. Res., 102, 1989: $240-248$

ROWLAND, D. J.: New advances in animal and human virus vaccines. Adv. Biotech. Proc., 8, 1986: $253-258$

THAPAR, M. A.-PARR, E. L. - BOZZOLA, J. J.-PARR, M. B: Secretory immune responses in the mouse vagina after parenteral or intravaginal immunization with an immunostimulating complex (ISCOM). Vaccine, 9, 1991: 129-133.

TRUDEL, M.-NADON, F.-SEGUIN, C.-BOULAY, G.-LUSSIER, G.: Vaccination of rabbits with a bovine herpesvirus type 1 subunit vaccine: adjuvant effect of ISCOMs. Vaccine, 5 , 1987: $239-243$

TRUDEL, M.-BOULAY, G.-SÉGUIN, C.-NADON, F.-LUSSIER, G.: Control of infectious bovine rhinotracheitis in calves with a BHV-1 subunit-ISCOM vaccine. Vaccine, 6 , 1988: $525-529$

WEISS, H. P.-STITZ, L.-BECHT, H.: Immunogenic properties of ISCOM prepared with influenza virus nucleoprotein, Arch. Virol., 114, 1990: 109-120

ZANETTI, M.-SERCARZ, E.-SALK, J.: The immunology of new generation vaccines. Immunology Today, 8, 1987: 18-25 
Plate XXIII.

Franz J. et al.: Preparation of ... pp. 37-41.

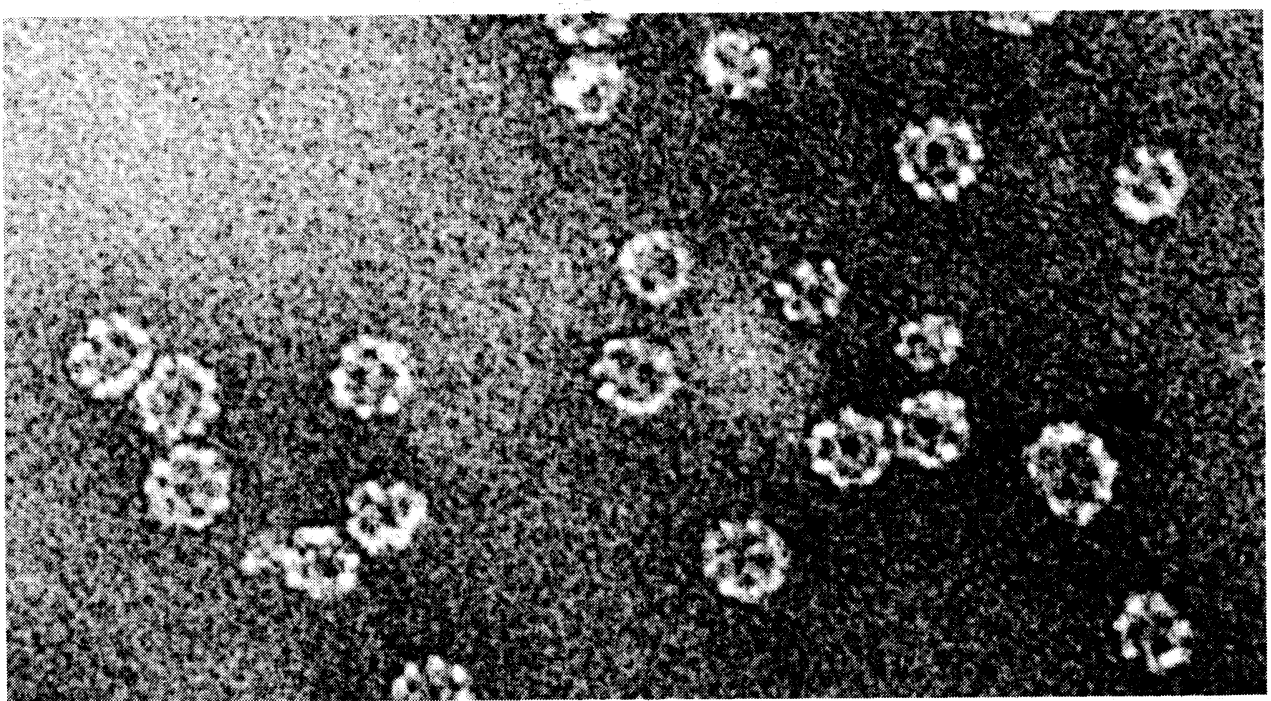

Fig. 1. ISCOM-BHV-1 - detail

C: $250 \mu \mathrm{g} \quad$ Quil A: $2000 \mu \mathrm{g}$

PC: $250 \mu \mathrm{g} \quad$ protein: $500 \mu \mathrm{g}$

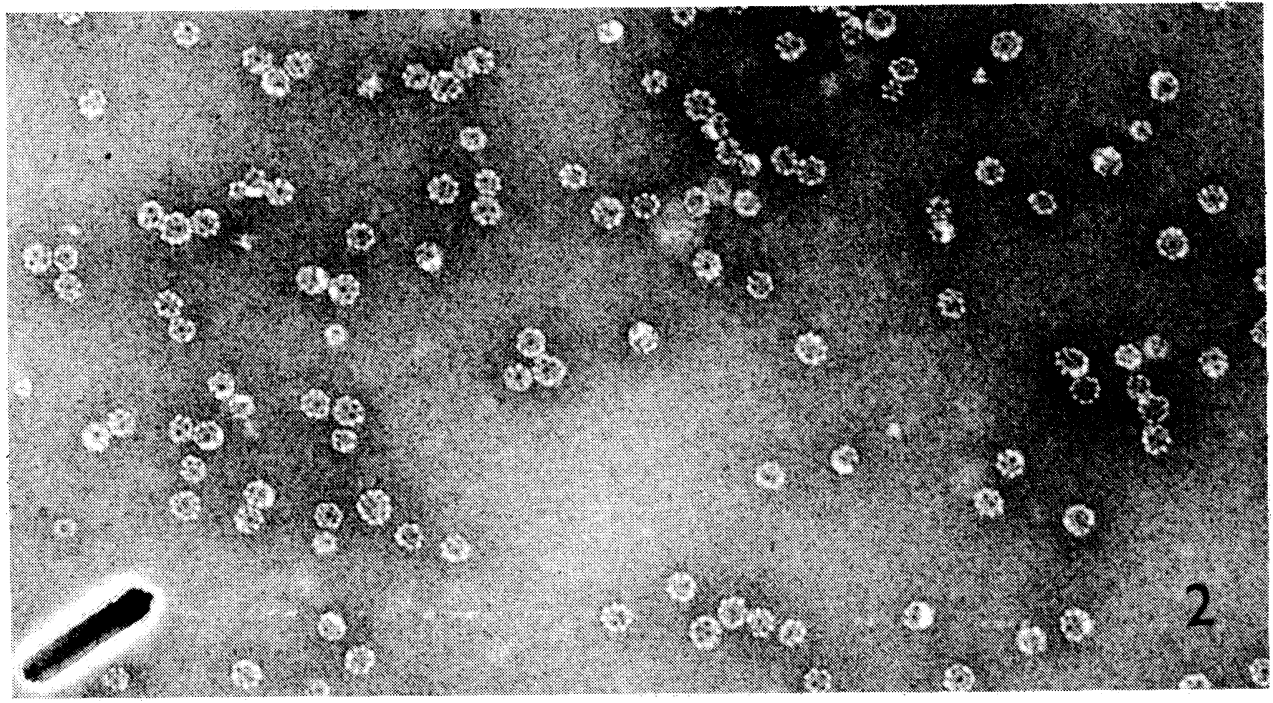

Fig. 2. ISCOM-BHV-1

$\begin{array}{llr}\text { C: } 250 \mu \mathrm{g} & \text { Quil A: } & 2000 \mu \mathrm{g} \\ \text { PC: } 250 \mu \mathrm{g} & \text { protein: } & 500 \mu \mathrm{g}\end{array}$

Magnification: $24000 x$ 


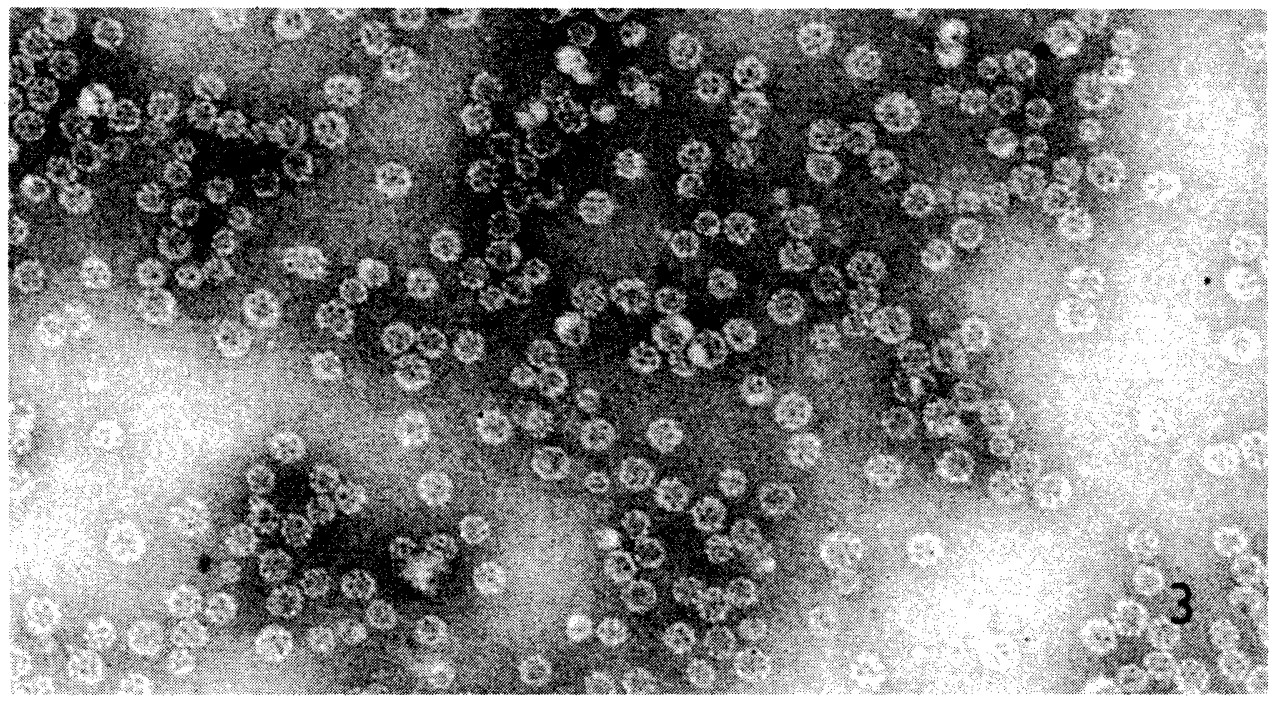

Fig. 3. ISCOM-BHV-1
$\mathrm{C}: 500 \mu \mathrm{g}$
PC: $500 \mu \mathrm{g}$
Quil A: $\quad 2000 \mu \mathrm{g}$
Magnification: $24000 \mathrm{x}$
$500 \mu \mathrm{g}$

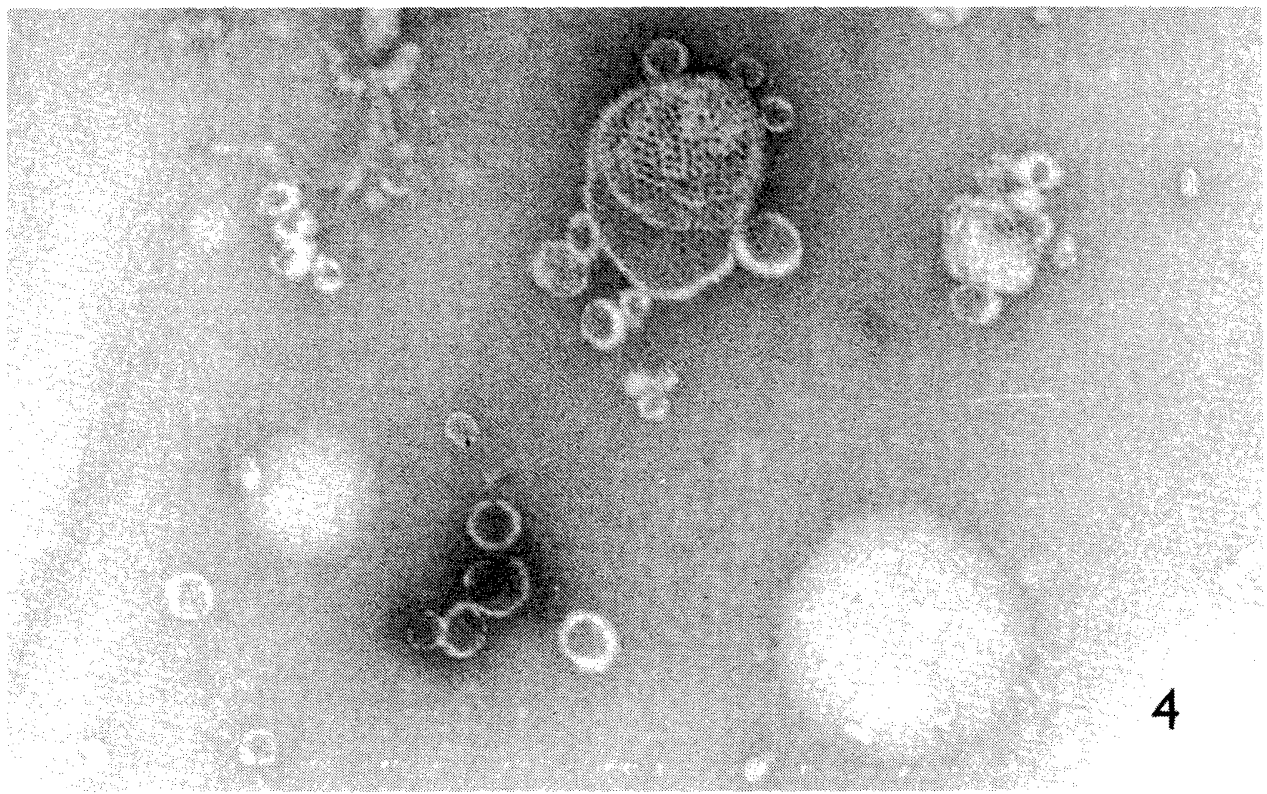

Fig. 4. ISCOM-BHV-1

C: $1000 \mu \mathrm{g} \quad$ Quil A: $2000 \mu \mathrm{g}$

PC: $1000 \mu \mathrm{g}$ protein: $500 \mu \mathrm{g}$

Magnification: 24000x 
Plate XXV.

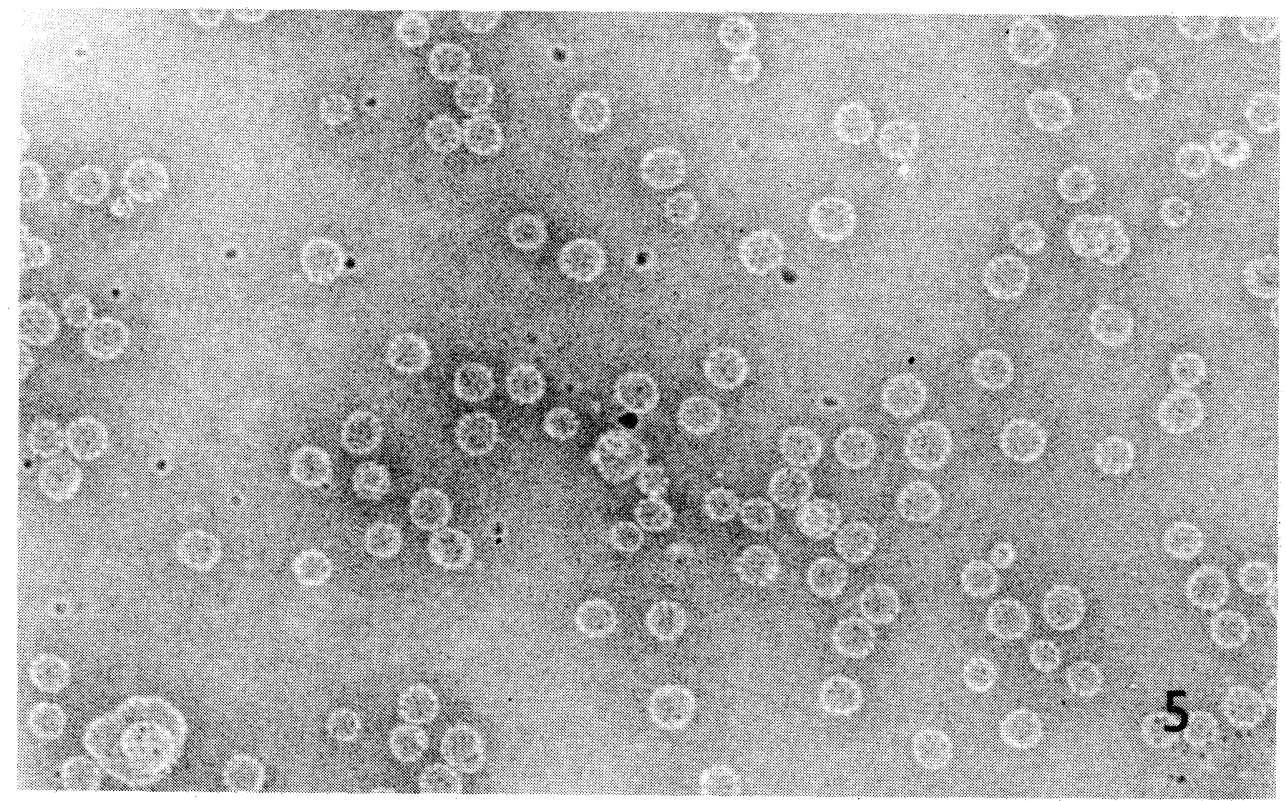

Fig. 5. ISCOM-BHV-1

$\begin{array}{llr}\text { C: } 1000 \mu \mathrm{g} & \text { Quil A: } & 4000 \mu \mathrm{g} \\ \text { PC: } 1000 \mu \mathrm{g} & \text { protein: } & 500 \mu \mathrm{g} \\ \text { Magnification: } & 24000 \mathrm{x} & \end{array}$

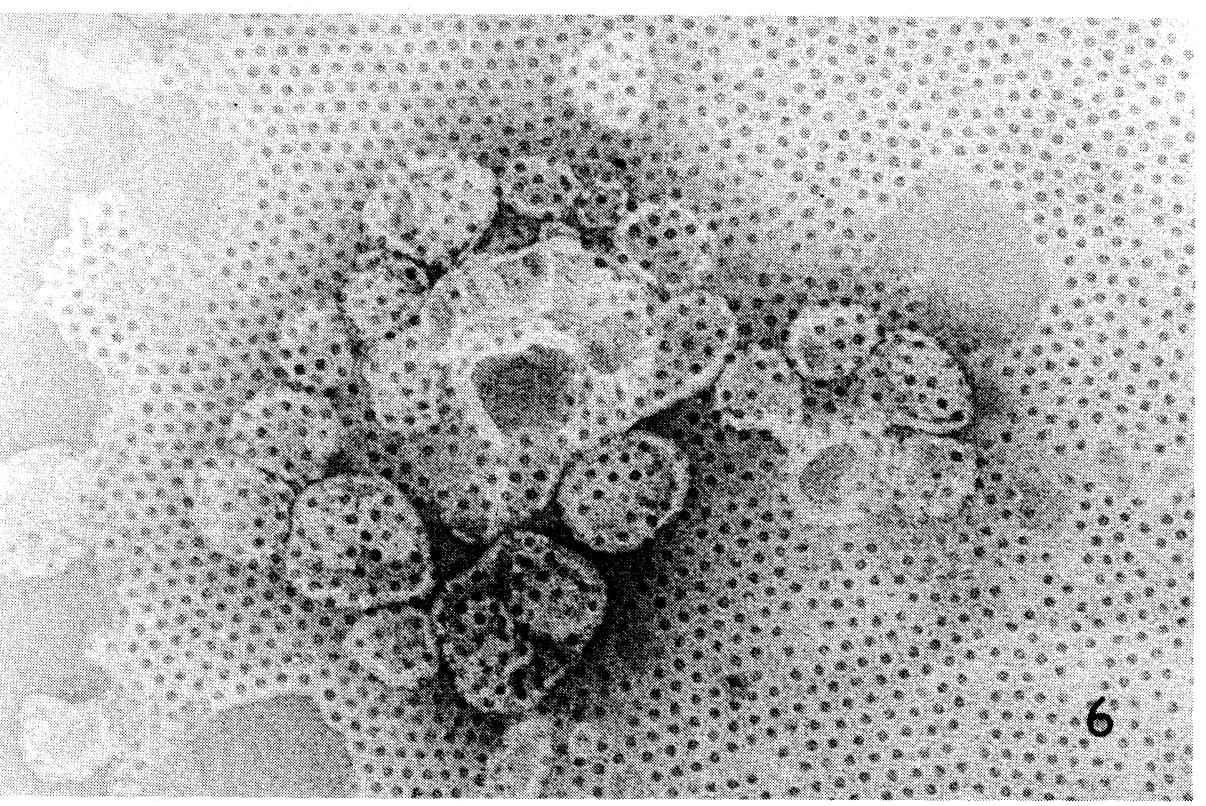

Fig. 6. ISCOM-BHV-1
C: $1500 \mu \mathrm{g}$
PC: $1500 \mu \mathrm{g}$
Quil A: $\quad 2000 \mu \mathrm{g}$
Magnification:
protein: $\quad 500 \mu \mathrm{g}$ 